ciples. He was so devoted to his duties that he labored to dispose of the business and hence was useful beyond many others. For it is not to be denied that for [all] parties, the bar and the public alike, it is often better to have litigation ended, if not always upon the most correct lines, than to be confronted with delays, whether from accumulation of cases or inattention of judges to the worls before them. Perfection in theory is not so important to the average mind as fair practical certainty and reasonable speed in decision. His opinions, therefore, because of his industry in their preparation-fair ability in discussionare entitled to and will stand well as a part of our legal literature. On the whole Judge Greene was a valuable judge and most worthy and valuable citizen.

\title{
FEARFUL DECLINE IN THE PRICE OF NEGROES
}

Misfortunes never come single. While the Democratic party is rent by Kansas feud, it is assailed even more dangerously by the terrible decline in the price of the Negro.

We cut the following from the Richmond South:

December 14, 1857.

Heavy Decline in Slaves! The Dispalch on Friday last, for the benefit of "country readers," on what it no doubt thinks reliable authority gave the price of the slaves in this market. To show that the prices given in the Dispatch are not to be had, and slightly artificial, and must be above what slaves are bringing, and to prevent owners and sellers of slaves from being misled, I request that you publish the sale of seven, made on Thursday by the leading house here, and probably the same who posted the Dispatch: A No. 1, field hand, black, 22 years old, $\$ 620$. No. 2, a woman, stout and healthy, a good cook, \$475. No 3 , a No. 1. brown, fancy woman, 26 years, good seamstress, $\$ 5300^{\circ}$ No. 4, man and wife, 40 and 30, man slightly unsound, taken in at $\$ 670$ for the pair. No. 6, a man, about $27, \$ 416$. Little niggers, from 5 to 7 years, so slow that they are generally sold in lots or by the dozen.

The above sale is regarded as a fair test of the market, as the subjects were fresh from the country, and fully guaranteed, and the auctioneer excrted himself to obtain high prices.-Verifier.The Iora Citizen, Des Moines, January 12, 1858. (In the newspaper collection of the Historical, Memorial and Art Department of Iowa.) 
Copyright of Annals of Iowa is the property of State of Iowa, by \& through the State Historical Society of Iowa and its content may not be copied or emailed to multiple sites or posted to a listserv without the copyright holder's express written permission. However, users may print, download, or email articles for individual use. 